\title{
الارتجال المسرحى بين عروض التعبير الحركى ومسرح المقهورين دراسة تحليلية لنماذج مختارة
}

\author{
إعداد \\ منى عبد المقصود عبد العزيز شنب

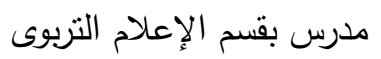 \\ كلية النزبية النوعية - جامعة المنوفية
}

\section{ملخص البحث}

تهدف الدراسة الحالية إلى معرفة الأسس العلمية للارتجال سواء فى عروض التعبير الحركى

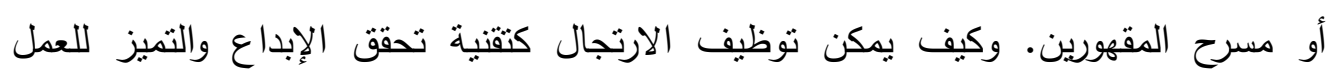

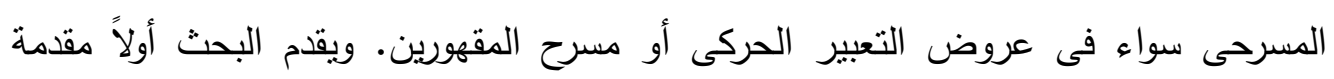

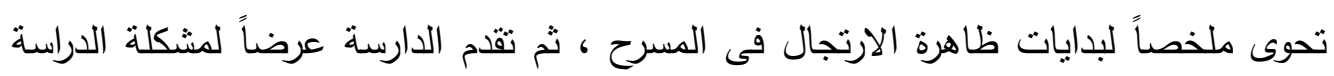
والأهمية والأهداف ، ثم منهجية البحث وأدواته ثم تستعرض الداستة التهات التحليلية من خلال تحليل العروض عينة الدراسة. وقد توصلت الدراسة إلى عدة نتائج أهمها:- ان العروض المقدمة لمسرح المقهورين ( عينة الدراسة ) تتصب على التركيز على المتفرج

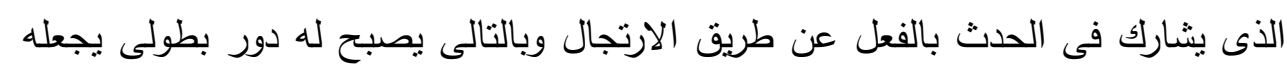
قادرا على القيام بالفعل الحقيقى فى الحياة.

اسفرت النتائج على أن أهم أسس الارتجال سواء فى عروض مسرح الراقي أفس أو مسرح

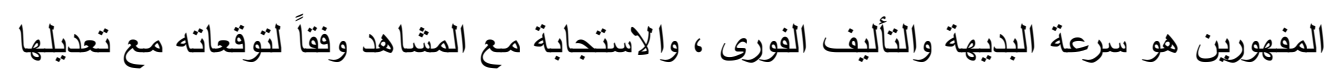
فى المسار الصحيح. 


\section{Abstract}

study aims at finding out the scientific bases of Current The improvisation, both in motifs or in the theater of the oppressed. And how to employ improvisation as a technique that achieves creativity and excellence for theatrical work, both in expressions of motion or the theater of the oppressed. The study presents a summary of the beginnings of the phenomenon of improvisation in the theater. The study presents the problem of study, importance and objectives, then the methodology of the research and its tools

\section{The study reached several results, the most important of which} are

The performances presented to the theater of the oppressed (sample study) focus on the spectator who is already participating in the event through improvisation and thus has a heroic role to be able to do the real thing in life

The results found that the most important foundations of improvisation, both in the theater performances of the dancer or the is the speed of the intuitive and instantaneous coppressed theater of the composition, and respond with the viewer according to his expectations and adjusted in the right track. 
بدأ المسرح قديماً معتمداً على الارتجال الفطرى ، حيث أنه لم يكن هناك نصاً أدبياً مكتوبا. ثم بعد ذلك عرفنا مرحلة التأليف والتى قامت على وضع نصوص مصنى مسرحية مؤلفة وبالرغم من وصولنا لهذه المرحلة وتطور الكتابات إلا أنه مازال الارتجال القائم على غياب

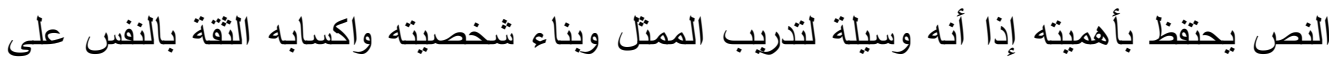

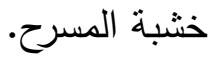
وقد يكون الارتجال فى وجود نص بحيث يخرج الممثل عن دوره ويأتى بالجديد الغير متفق عليه كما كنا نجد محمد صبحى ، سمير غانم فى المسرحيات الكوميديا والتى كانوا يخرجون فيها عن النص الأصلى ويرتجلون ما يصل إلى قلب الجمهور بهدف المتعة والإضحاك. ولو نظرنا إلى عروض التعبير الحركى وعروض مسرح المقهورين فهما عبارة عن فكرة لتوصيل رسالة أو قضية معينة يتم ارسالها عن طريق أجساد الراقصين كما فى عروض التعبير

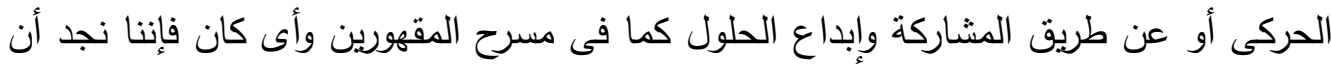

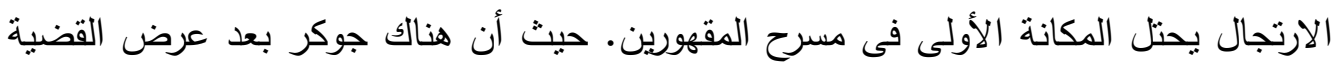

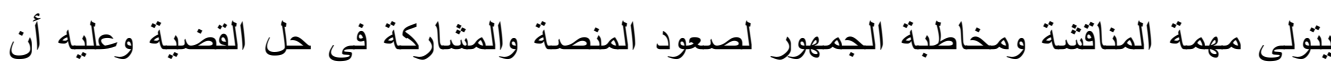
يقود المسيرة للوصول إلى الحلول الإبداعية والإيجابية للمشكلة أو القضية المعروضة. وبالتالى نلاحظ ان الارتجال هنا لم يقتصر على المؤدى فقط بل نتاول المتلقى مستمع الإنى

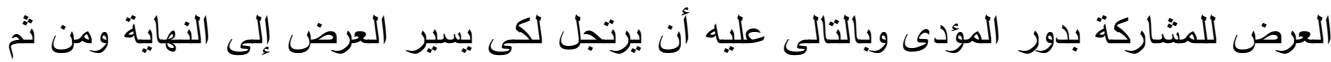

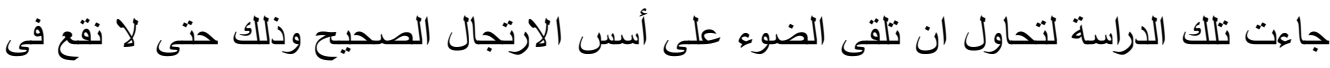

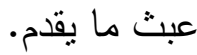

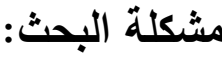

هناك خلط بين الارتجال المسرحى كتقنية أو تكنيك يستخدم فى المسرح وله دوره الذى يقوم به

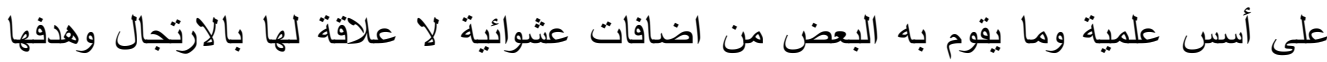

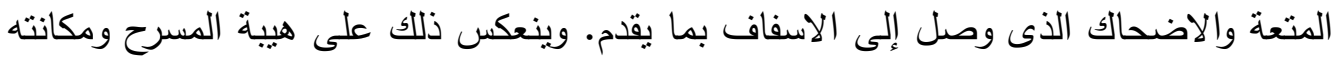
ومن هنا تتشأ المشكلة البحثية فى ضرورة الكثف والتوضيح للأسس الصحيحة للارتجال المسرحى سواء فى عروض التعبير الحركى أم مسرح المقهورين. 


\section{وينبثق من المشكلة عدة تساؤلات:}

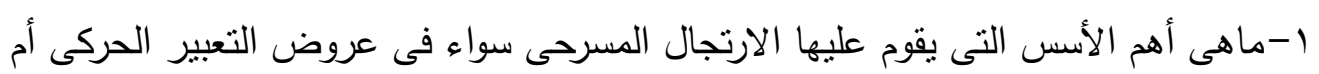

$$
\text { مسرح المقهورين؟ }
$$

ץ- ما الهدف من توظيف الإرتجال سواء فى عروض التعبير الحركى أم مسرح المقهورين؟ r- هل نم توظيف عنصر الارتجال بفاعلية فى عروض مسرح المقهورين ( عينة الدراسة)

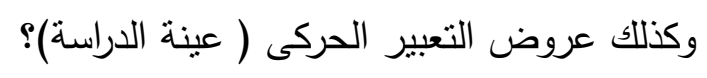

ع-ما مدى نجاح الارتجال كتقنية تم توظيفها فى عروض التعبير الحركى ومسرح المقهورين؟

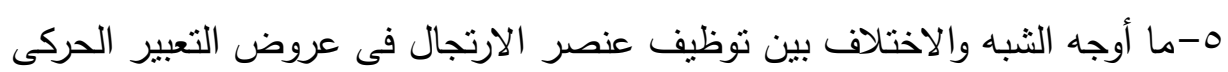

ومسرح المقهورين

\section{أهمية البحث}

تتصدى تلك الدراسة لوضع الأسس والقواعد التى يقوم عليها الارتجال المسرحى وذلك

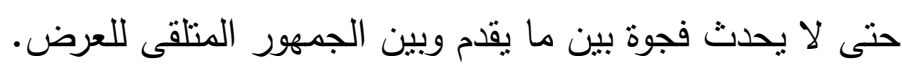

\section{أهداف البحث}

يههف البحث الحالي إلى رصد الأسس الصحيحة للارتجال التى يحتم على الراقص الالنزام بها فى عروض التعبير الحركى أو المتلقى فى عروض مسرح المقهورين.

منهج البحث

يعتمد البحث على المنهج الوصفى التحليلى فى تحليل ووصف ضوابط وأسس الإرتجال

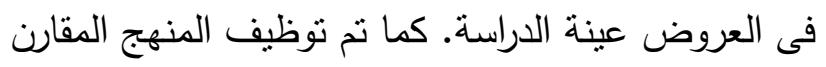
أدوات البحث استخدمت الباحثة تحليل المضدون فى تحليل العروض عينة الدراسة

عينة البحث

طبق البحث الحالي على عينة من عروض التعبير الحركى " فرقة الرقص بدار الأوبرا"

$$
\text { وهى : }
$$

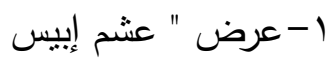

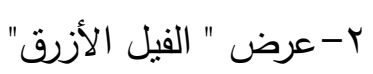


r-عرض " موضلانا" كما تم تطبيق على عروض مسرح المقهورين التابعة للمخرجة نورا أمين " المشروع

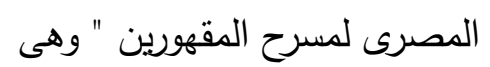
ا-عرض " حكاية المواطن والمخبر" ب-عرض " حكاية سكر" " برض " حكاية سماح" مبرات البحث ا-القصور الذى يحدث فى توظيف الارتجال كتقنية يتم استخدامها سواء فى عروض التعبير الحركى أو مسرح المقهورين من العثوائية أو القصد الخروج عن النص بهدف الإضحاك وما إلى ذلك.

ץ-النظر إلى الارتجال على أنه تقنية تضاف إلى النص لإخفاء ما به من عيوب أو لمجرد الضحك مما أدى إلى عزوف البعض عن استخدامه على أساس أن النص السليم ليس بحاجة إلى الارتجال. مصطلحات البحث

الارتجال

الانجاز أو القيام اللحظى والآنى بشيء لا متوقع وغير جاهز وهذا بعنى:

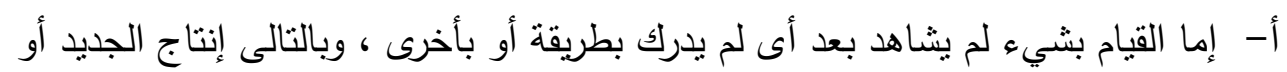
المخالف للمألوف. ب-انجاز حدث غير متصور ت - تانجاز حدث لا إرادى وغير مقصود. وهناك من يرى أن الارتجال هو " أداة تحفيز على الإبداع ، والتواصل ، والتعلم ، والنمو، والاستكثاف ، وتعليم الناس سرعة التفكير والاستمتاع به. وترى الدارسة أن الارتجال هو الإتيان بالجديد الغير مسبق والذى يضبف إبداعاً إلى له

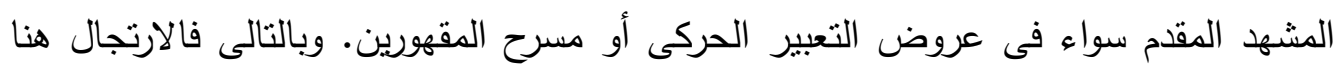
ليس فقط إصدار حلول لقضايا معروضة كما فى مسرح المقهورين ، ولكن لابد وأن تكون نلك الحلول إبداعية تأتى بالجديد وتساهم فى حل المشكلة المعروضة، أو الاتيان بالجديد من خلال الحركة كما فى عروض التعبير الحركى عينة الدراسة وليس حركة ترجمة للحوار فيصبح من السهل الاستغناء عنها. 


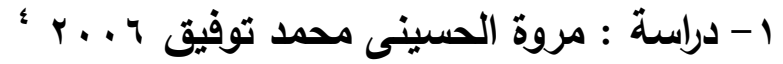

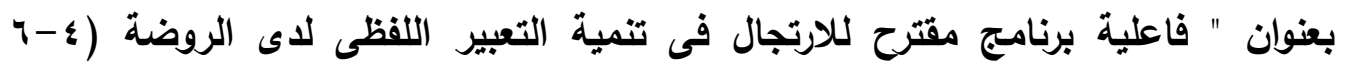

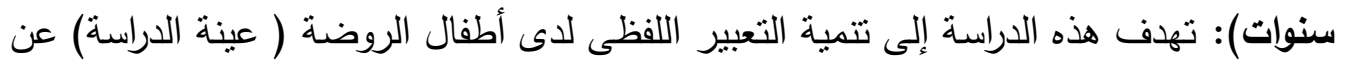

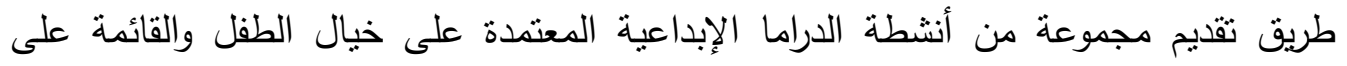

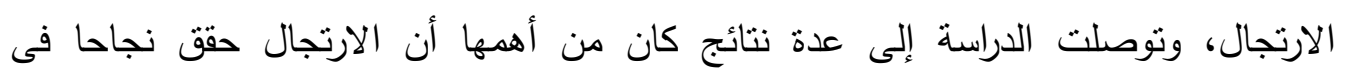
الأنشطة المقدمة وذلك بعد خلق جو من الحرية للطفل ساعده على التعبير عن نفسه عن طريق الارتجال.

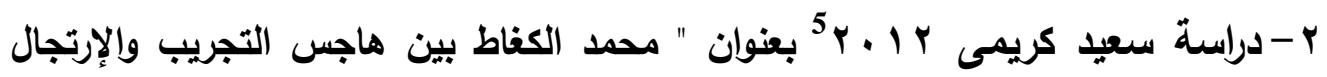
المسرحى ": تهدف هذه الدراسة إلى نتاول بعض أعمال المخرج المغربى محمد الكغاط وبيان

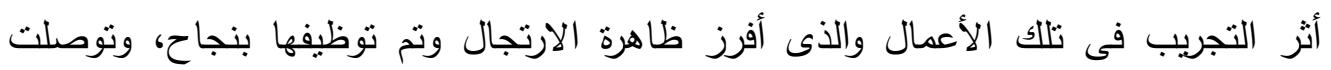
الدراسة إلى عدة نتائج أهمها أن الارتجال تقنبة يتم استخدامها على أسس مدروسة تضيف إلى الى النص.

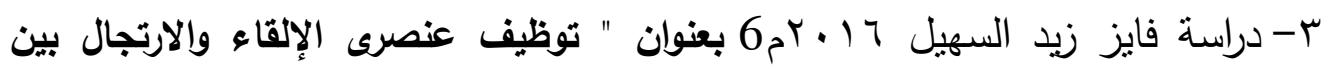
إخراج العروض المسرحية والتتليفزيونية فى دولة الكويت": هدفت الدراسة إلى معرفة كيفية توظيف عنصرى الإلقاء والإرتجال فيما بين تعامل الملقى مع شخصية المتلقى وكيفية نوصيل

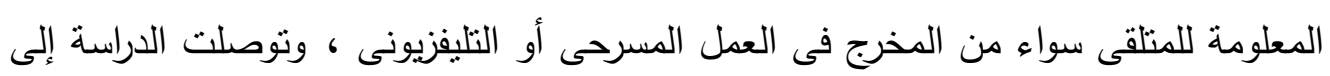

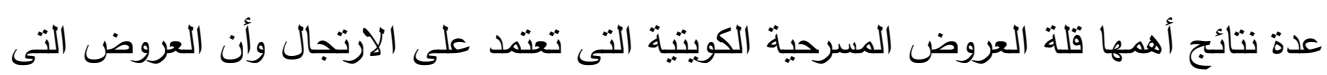
اعتمدت على الارتجال كانت لمجرد الضحك.

\section{التعليق على الدراسات السابقة}

- اتفقت الدراسات السابقة على أن الارتجال تقنية يتم استخدامها لإيجاد جو من الحرية فى التعبير عن النفس كما فى دراسة مروة الحسينى. - أثتتت دراسة فايز السهيل 17 ـ ب بعض الأخطاء التى تتتج من نوظيف الارتجال بعشوائية لإثارة الضحك فقط. - تتفق الدراسة الحالية مع دراسة سعيد كريمى r ا ـ ب على أن الارتجال تقنية يتم استخدمها على أسس مدروسة تضيف الجديد والمبدع للعمل المقدم. 


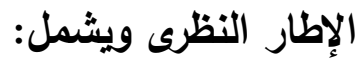

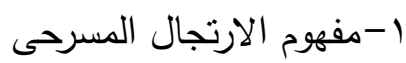

r- بأهمية الارتجال المسرحى الارنجال المسرحى

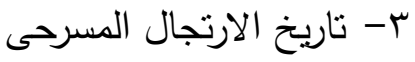

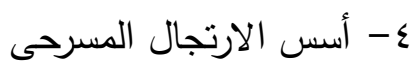

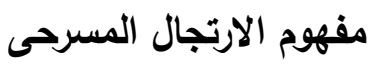

الارتجال هو " أداء غير محضر تتشرك فيه عملية التأليف والأداء فى آن واحد وبشكل فورى ويقوم على الذاتية والفردية والتصور الثخصى ، وبذلك يجمع بين التفكير والأداء فى آن

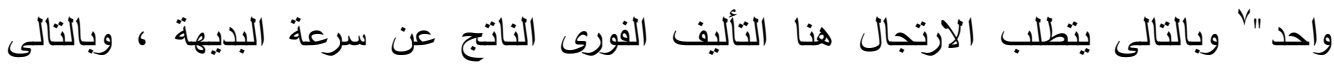
فالمشاهد أو المتلقى مطالب بالارتجال فور توقف العرض من أجل إصدار حلول للمشكلة المعروضة فى شكل حوار ارتجالى غير معد مسبقاً ولكنه نابعاً من اللحظة الحالية ، وبالمثل

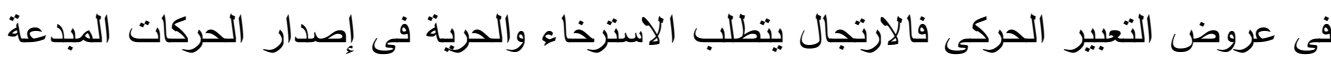
فى اللحظة الحالية وبشكل فورى.

أهمية الارتجال المسرحى 1-يعطى الممنل فرصة " تحقيق الهدف من المشهد " والذى لم يتحقق ما لم يكن هناك تدريب المبال

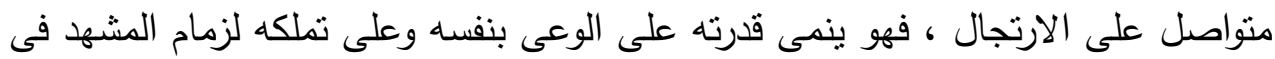
نفس الوقت.

r-مساعدة الممتل على إنشاء علاقة وإحداث تواصل مع زميله على المسرح ، فأحيانا تفشل كلمات المؤلف فى تحقيق هذا التواصل ، ولهذا نجد أن ستانسلافسكى كان ينصح مدئه رئليه

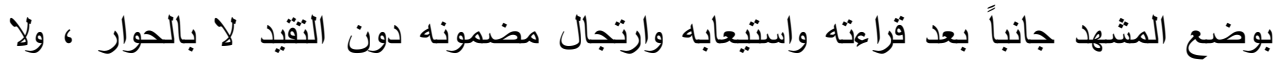

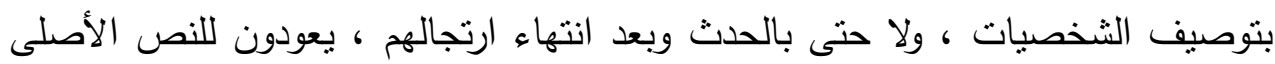
وقد التبسو روئة أعمق وبصيرة أثند نفاذا. r-يجبر الممثل على " الكلام والإنصات" وهو أمر يحتاج إلى تدريب. ففى الارتجال يكون

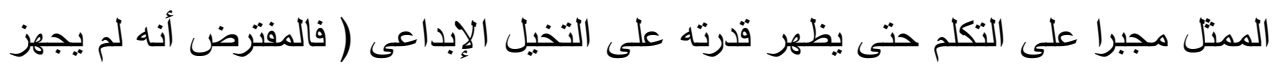

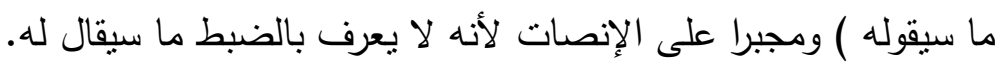


ع-الارتجال أيضا يساعد المثل على تطوير إحساسه بالمرة الأولى - أحد الثروط الجوهرية

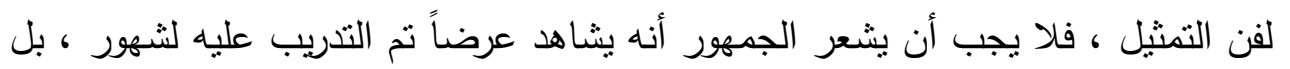

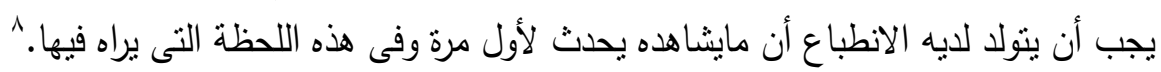

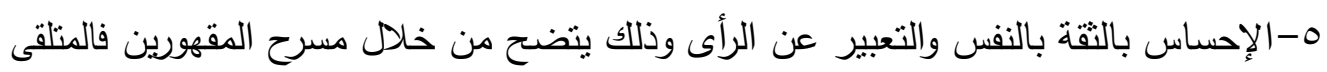

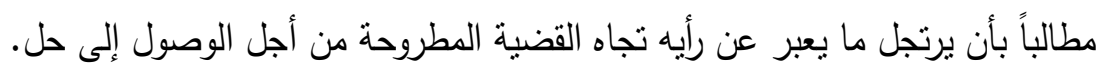

تاريخغ الارتجال

الارتجال شكل قديم من أنثكال فن التثثيل ، ومن أعظم أشكاله إثارة فى القرنين السادس

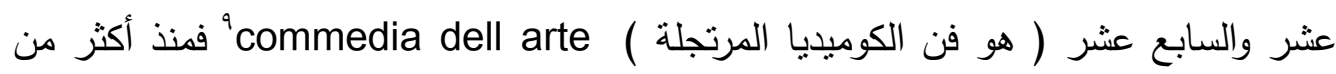

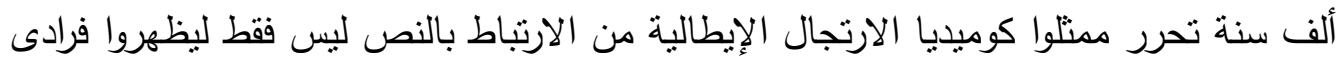

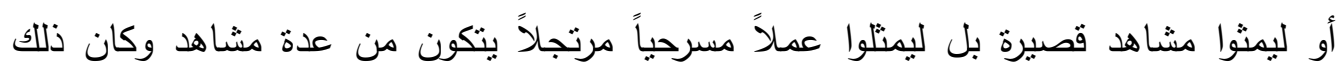

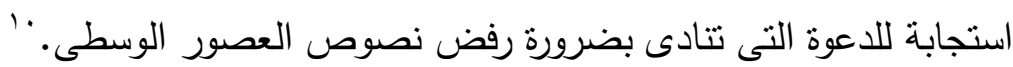

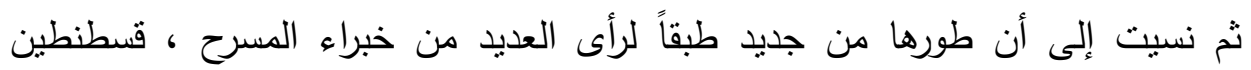

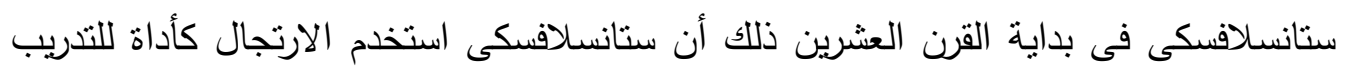
لاستيعاب فعل صعب بالسماح للممثل بممارسة سلوكه فى مواجهة الثخصية لموقف مشابهابه،

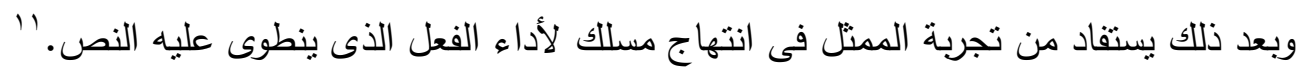

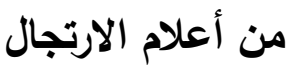

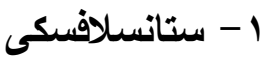

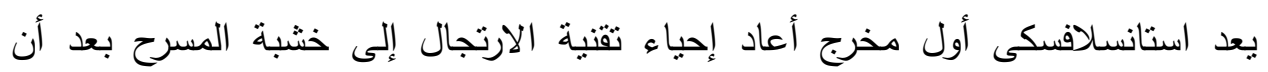
استخدمتها الكوميديا دى لارتى الإيطالية فى القرن السادس عشر اعلى الميلادى، ومن أشنكال

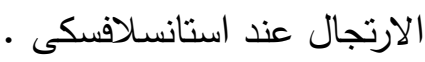

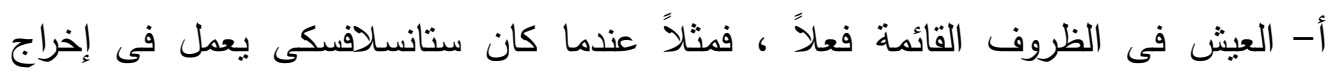

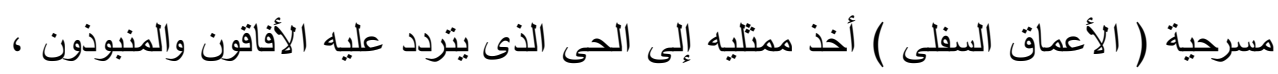

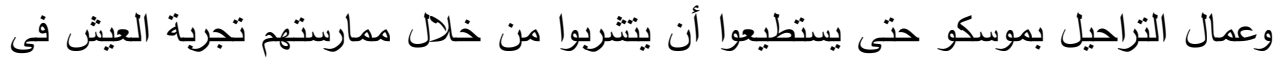
الوحل والقذارة. ب-الثكل الثانى الذى استخدمه ستانسلافسكى هو إيجاد موقف مشابه لذلك الموقف فى الحدث المسرحى ، ولكنه برتبط بصلة مباشرة بحياة الممتل وظروفه. والارتجال حول

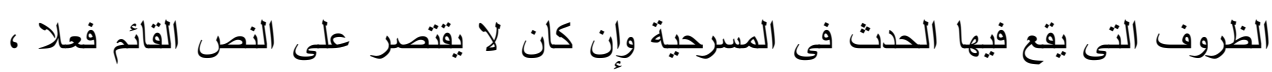

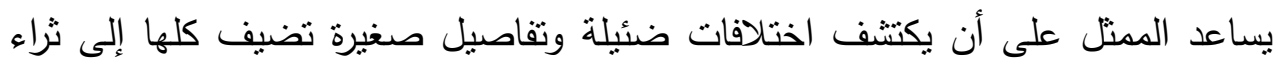

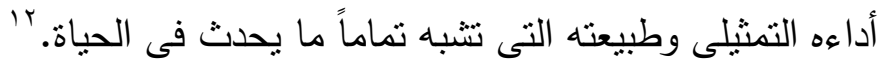


نجد أن الأشياء التى يدين بها المسرح الحديث لكوب وهى كالاتى بلاترتيب: الألعاب

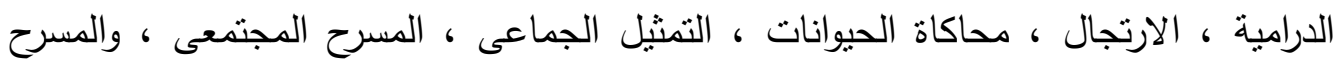

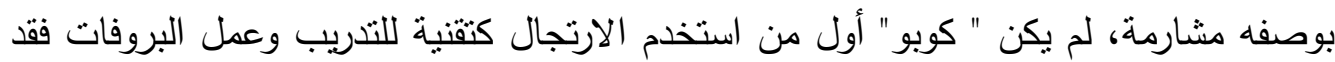

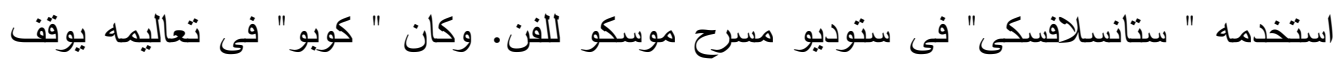

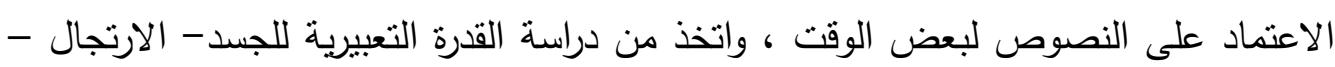
نقطة انطلاقه.

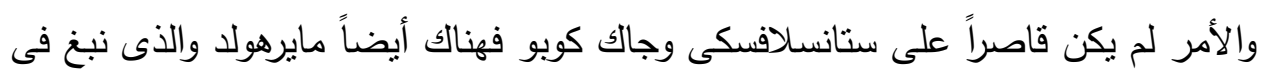

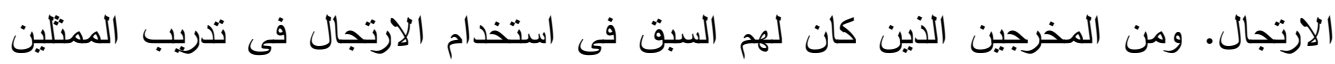

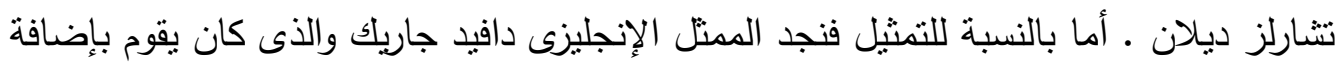
الجديد إلى نصوص شكسبير ولايكتقى بالحذف وإنما كان يضيف كل ما من شأنه أن يخدم العمل ويحقق الهدف. وبالتالى نجد أن الارتجال ليس وليد اللحظة فقد بدأ مع المسرح وتبلور

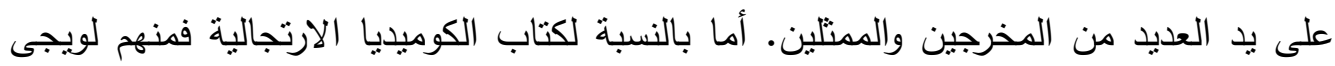

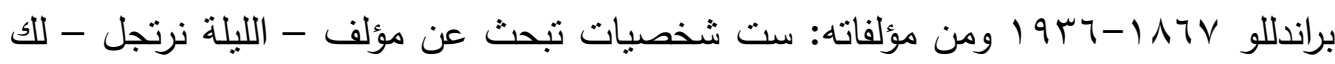
شيخ طريقته.

$$
\begin{aligned}
& \text { أسس الارتجال } \\
& \text { 1-وضع خطة للارتجال } \\
& \text { r-الخيال وتركيز الانتباه } \\
& \text { ب-سرعة البديهة } \\
& \text { ع-التأليف الفورى } \\
& \text { ه-الإبداع }
\end{aligned}
$$

\section{وضع خطة للارتجال}

لابد من وضع خطة للارتجال سواء بالنسبة للمشاهد أو المتلقى فى مسرح المقهورين أو

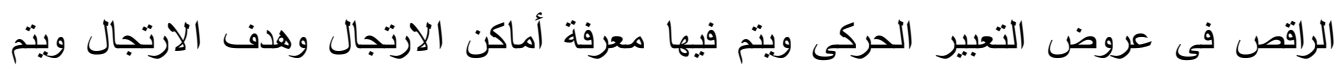

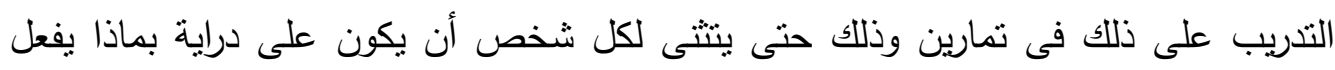

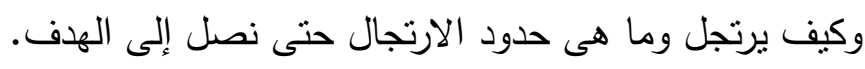

الخيال وتركيز الانتباه

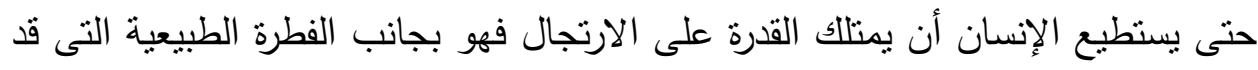

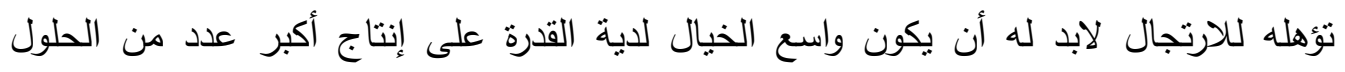


لمشكلة معروضة كما فى مسرح المقهورين أو إصدار حركات عديدة كما فى عروض التعبير

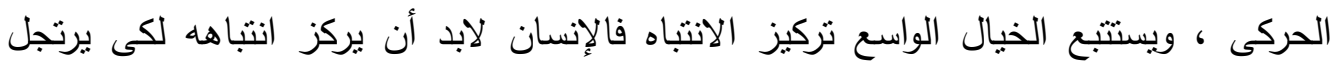
بطريقة صحيحة تخدم العمل المقدم.

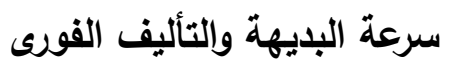

سرعة البديهة هى بمثابة فطنة الثخص وهى قد تكون غريزة فى الإنسان وقد تكتسب عن طريق تمارين الارتجال ويستتبع سرعة البديهة التأليف الفورى.

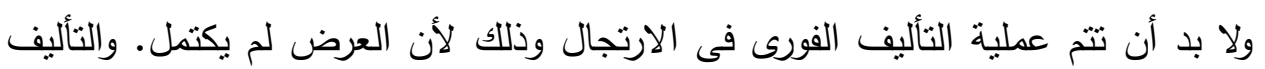

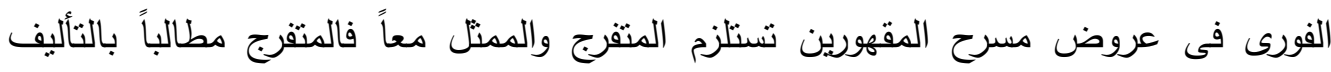
الفورى لما خطر على ذهنه تجنه القضية المعروضة ، والممثل مطالباً بالتأليف الفورى أيضاً من أجل التجاوب مع المشاهد أو متلقى العرض من أجل الوصول إلى حلى لول للقضية المطروحة.

وعملية التأليف الفورى تحتاج إلى تدريب من أجل تحقيق الهدف ، وقد وضع أوجستوبوال

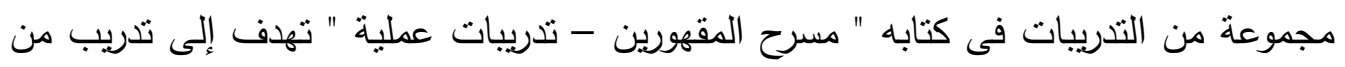
يقوم بعملية الإرتجال بعملية التأليف الفورى وفقاً لأسس عملية صحيحة حيث يقول أوجستوبوال

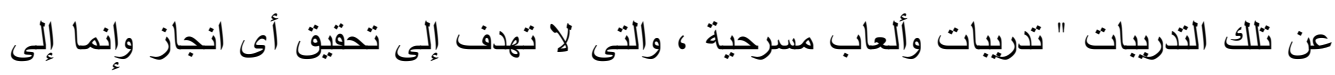

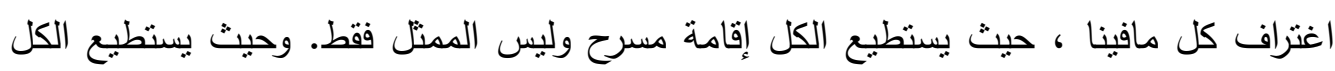

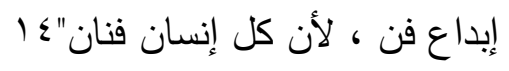

الإبداع

يجب على المرتجل أن يدرك أنه كلما ازداد وضوحاً ، بدأ أكثر ابداعاً ، حتى الناس

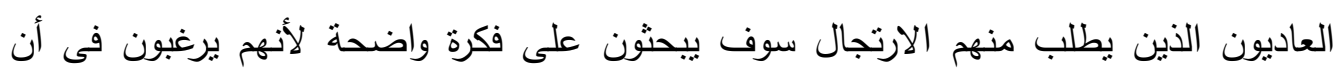
يعتقد أنهم حاذقون.

ومما يذكر أن عملية الإبداع لدى الممثل كانت فى الأصل تتطابق مع عملية الارتجال فى المسرحية الإيمائية ، أى مع المشهر الحركى. 17 وبالتالى نصل إلى نتيجة أن الارتجال ليس فقط إصدائه الصدار حواراً أو حركات بطريقة فورية وغير معدة مسبقاً ولكن يضاف إليها الإبداع والتميز الذى يضفى خصائصه الإنه على العمل سواء عروض التعبير الحركى أو مسرح المقهورين. 


$$
\begin{aligned}
& \text { الجانب التحليلى } \\
& \text { وسوف نتتاول ثناثة عروض وهى كالتالى :- } \\
& \text { 1- }
\end{aligned}
$$

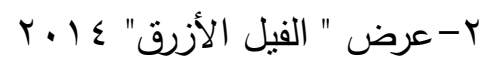

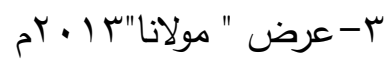

- أولاً: نتناول عرض " عشلاناسم إبليس " وبيان كيف تم توظيف الارتجال كتقينة فى خدمة فكرة

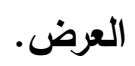

يدور العرض حول الصراع الموجود بين الخير والثر وذلك فى مسيرة التطور الإنسانى منذ بدء الخليقة حتى الآن ويتكون العرض من سبع مشاهد.

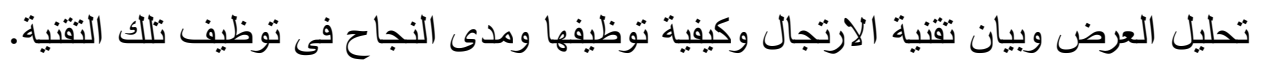

لم يكن استخدام الموسيقى قاصراً على الآلات فقط ولكن كان يتخلله الكلمات وبالتالى التى الته

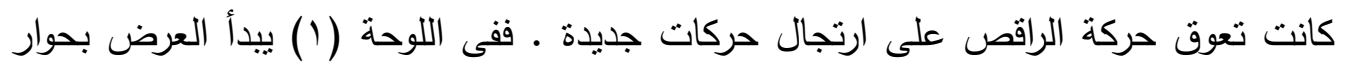

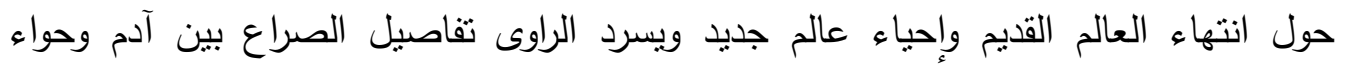

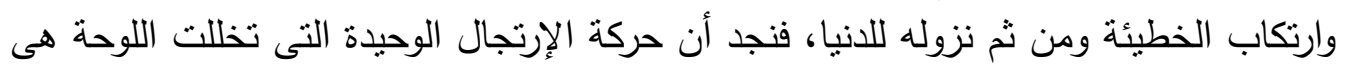

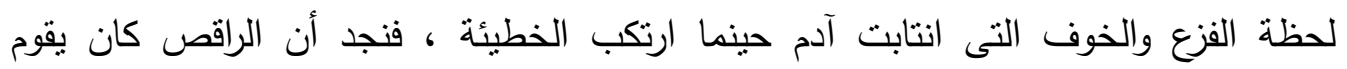

$$
\text { بارتجال حركات منل ( القفز - الجرى - الإنزلاق). }
$$

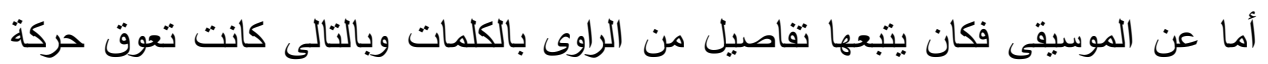

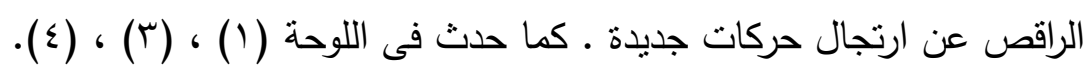

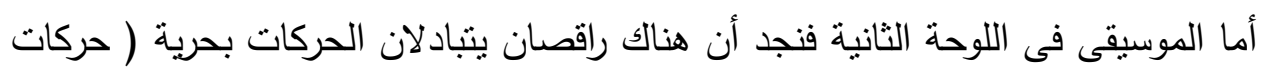

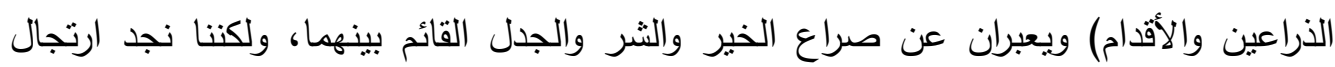
لحركات جديدة فقد كان أحد الراقصين يستخدم ذراعه فى وسم دائرة.

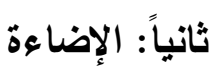

استخدم العرض فى معظمه الإضاءة الجانبية لإضفاء شكلاً على حركة الراقص وبالتالى الإه إعطائه حرية أكثر فى ارتجال حركات بالذراعين والأقدام. ثالثاً: الملابس

معظم راقصى العرض كانوا يرندون بدلة الجسم السوداء وكان ذلك متتاسباً مع فكرة

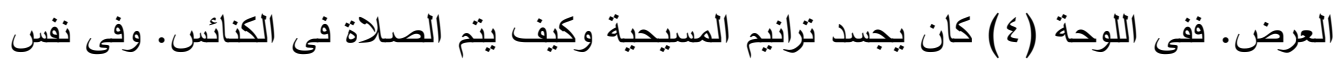
اللوحة كانت السيدة العذراء ترتدى اللباس الأسود. وقد ارتدى الراقص بدلة الجسم والتى كانت 
مصنوعة من قماش شفاف وبالتالى كنا نجده يرتجل حركات الصلاة بصورة عشوائية ولا إرادية. ولم يتم ارتداء الملابس الثقبلة التى كانت من الممكن أن تعوق الراقص على ارتجال حركات جديدة.

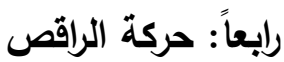

اختلفت حركة الراقصين فيما بينهم فى ارتجال الحركات فى كل لوحة من لوحات العرض الورات

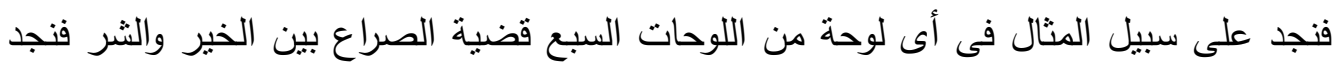

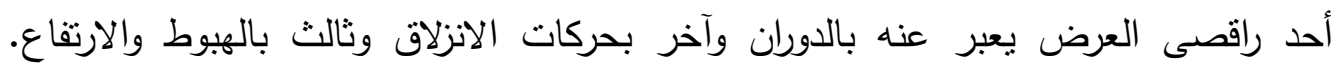
وبالتالى فكل راقص كان يرتجل حركته حسب قدراته وإكانياته الجسدي ووفقاً لما تعلمه من بن باتل

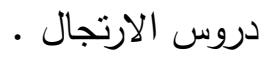

وكان هناك بعض المعوقات التى تعوق حركة الراقص عن ارتجال حرمات جديدة وبطريقة

$$
\text { عفوية وهى:- }
$$

ارتباط الموسيقى بالكلمات ( الراوى) كما حدث فى اللوحة (1) فالكلمات كانت تعوق الراقص على ارتجال حركات جديدة وكانت مجمل حركة كل راقص هى ترجمة لما قيل ،

$$
\text { وبالتالى لم يكن هناك مساحة للارتجال. }
$$

ا استخدام المواويل وبالتالى اصطحاب موسيقى معروفة ، ومن ثم فالراقص مقيد بحركات معينة ولم يكن لايه حرية فى التتوع وارتجال حركات جديدة لم يكن متفق عليها مسبقاً.

خامساً: المؤثرات

تم استخدام ظلال موزعة وذللك لإتاحة الحرية لكل راقص فى ارتجال حركات تعبر عن

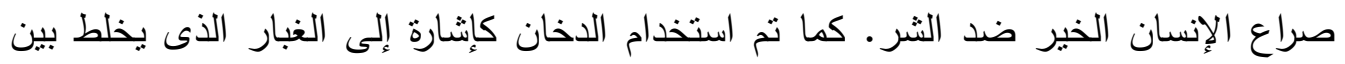
الأمور الخيرة والثريرة.

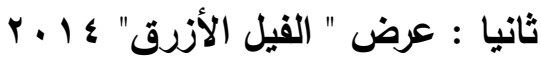

العرض مأخوذ عن روايه أحمد مراد ويدور حول دكتور بحيى طبيب الأمراض النفسية الذى ينقطع عن عمله مدة خمس سنوات وهو على رأس العمل وبعد ذلك يثقابل مع مديرة

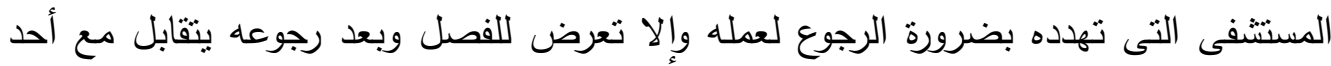
أصدقائه وهو شريف ( مريض نفسى) فيحاول دكتور يحيى دراسة مابداخله ويرى أنه مرآة تعكس مابداخله أيضاً. 1-الموسيقى : كانت الموسيقى خالية من أى كلمات واتسمت بالتنوع فى الإيقاع وبالتالى كانت تتيح حرية للراقص لارتجال حركات جديدة، استخدم الناى الحزين فى أكثر من لوحة 
من لوحات العرض مع تغير الموسيقى وإيقاعتها وبالتالى إتاحة الحرية للراقص لإرتجال حركات جسدية كالقفز والدوران بشكل انسيابى يتيح الحرية للراقص فى حركة جسده

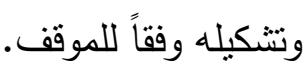

ץ-الإضاءة :استخدمت إضاءة أمامية فى معظم لوحات العرض وكانت تتيح حرية أكثر للراقص لإرتجال حركات فورية وسريعة كما أنها حولت أجساد الراقصين وكأنها أثنكال منحوتة.

ץ-الأثاث : عبارة عن أثنكال مفرغة ومنحوتة ساعدت على سهولة حركة كل راقص وارتجال حركات جديدة.

ع-الملابس : لم يكن هناك استخدام للملابس الواسعة التى أعاقت الراقص عن حركته ومن

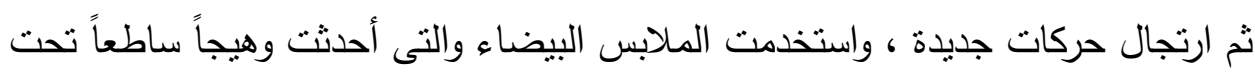
الأضواء وكان ذلك مناسباً لشخصية دكتور يحيى، أما بالنسبة لألوان الملابس فالراقينصين

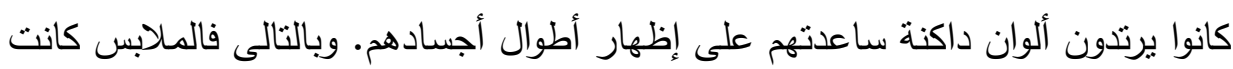
مناسبة لإتاحة الفرصة أمام كل راقص لإرتجال الحركة.

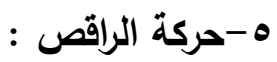

* فى اللوحة التى تقابل فيها دكتور يحيى مع مدير المستشفى وتهديدها له بضرورة رجوعه لعمله لأنه منقطع عن شغله منذ خمس سنوات وهو مازال على رأس العمل. فنجد أنه لم

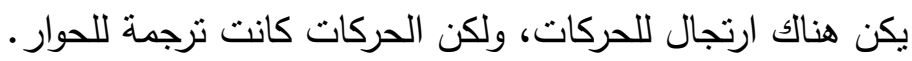

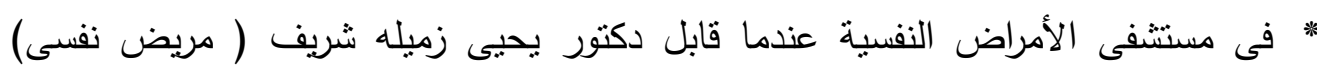
وحاول استرجاع الماضى. فكانت حركات طبيعية ولكن الراقص كان يرتجل حركات المريض النفسى بتلقائية وحتى مع وجود حوار بينه وبين دكتور يحيى فكانت ردود الفعل

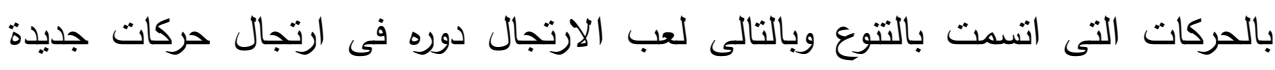

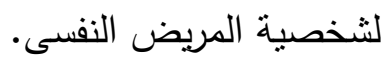
* مما سهل أيضاً حركة كل راقص وساعده على الارتجال الحركى هو عدم ارتداء الأحذية

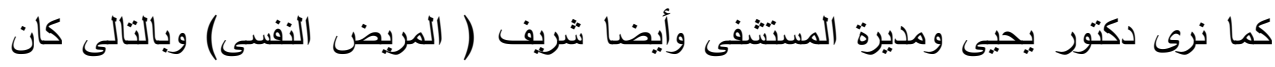
ذلك أحد الأسباب التى سهلت حركة كل راقص وساعدته على ارتجال حركنه بسهولة كما

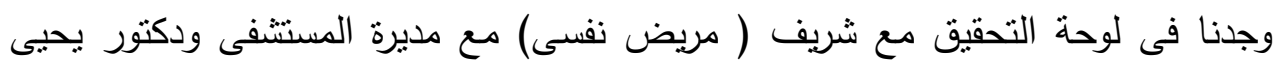
فنجد شريف كان يرتجل العديد من الحركات التى يقوم بها المريض النفسى. 


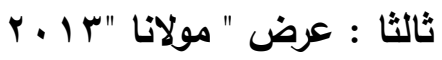
فكرة عرض " مولانا" هى نقلاً عن رواية لإبراهيم عبسى ، وتدور حول إحدى الثخصيات

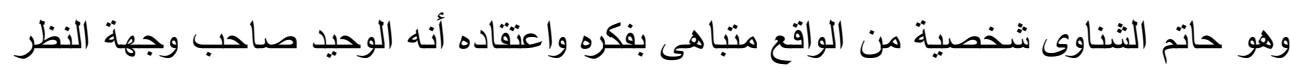

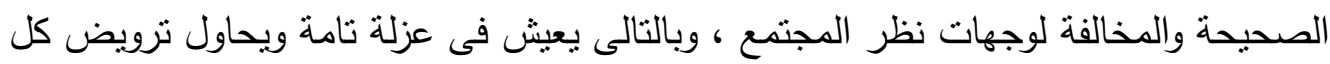
شيء بدلاً من التصادم معه حتى وإن كانت السلطة.

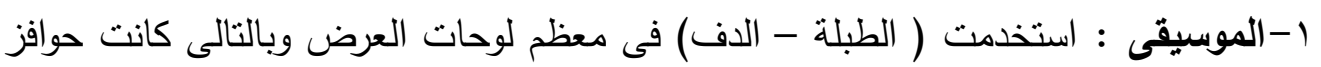
للحركة اتاحت للراقصين ارتجال حركات عفوية اتسمت بالتتوع تبعاً لتتوع الإيقاعات المستخدمة، كما استخدمت " آلات النقر" والتى اتاحت للراقص الحرية فى ارتجال حركات

\section{جديدة.}

ץ-الإضاءة : تتوعت اتجاهات الإضاءة ورافقت حركة كل راقص وبالتالى اتاحت له الفرصة فى ارتجال عدد لا نهائي من الحركات كما أن مساحة المسرح الخالية من قطع الأثاث

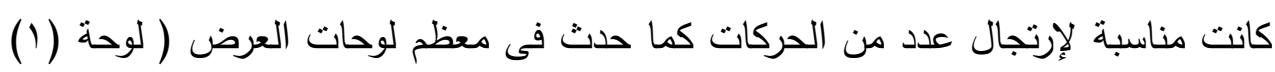

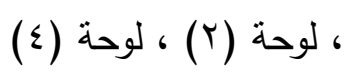

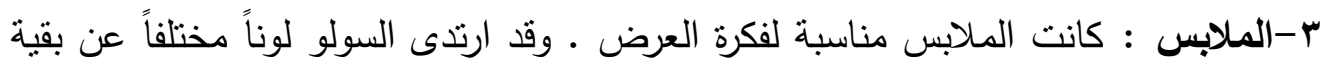

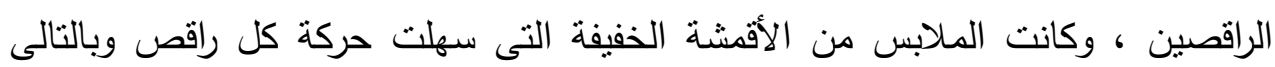
ساعدته على ارتجال حركات جديدة لم تكن معروفة من قبل.

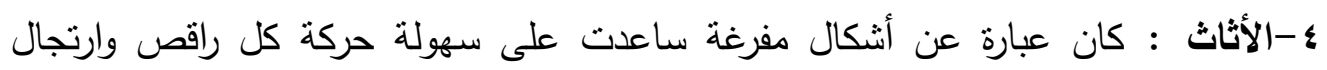
حركات جديدة. ه-حركة الراقص : تتوعت حركات الراقصين • وكان كل راقص يقوم بارتجال الحركة التى

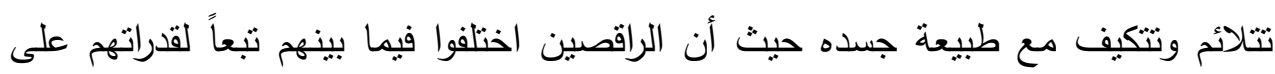
إنتاج وارتجال الحركات المعبرة.

\section{ثانباً: عروض مسرح المقهورين}

تتاول البحث ثلاثة من العروض التى قدمتها المخرجة نورا أمين فى مكتبة أكمل مصر

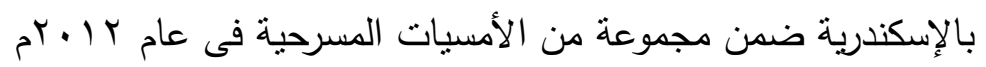
وهى : حكاية سماح حكاية المواطن والمخبر حكاية سكر 
وقد اشترك فى التمثيل مجموعة العمل الخاصة بفرقة نورا أمين والمتتقلة فى محافظات مصر المحتلفة وهم ( رامز أثرف - محمود بدير - رفعت عبد العليم- أسامة حلمى - ندى

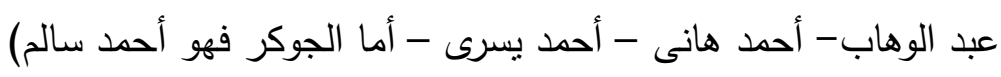

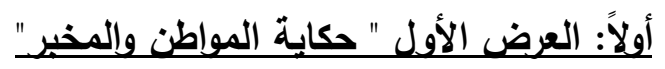

العرض قائماً على الإرتجال فهو يعالج حرية الفكر وأيضاً يتتاول دستورية القوانين بالنسبة لأى شيء فى المجتمع ، فالعرض يقدم شاب على الكورنيش يضع يده على خطيبته ، يقابله

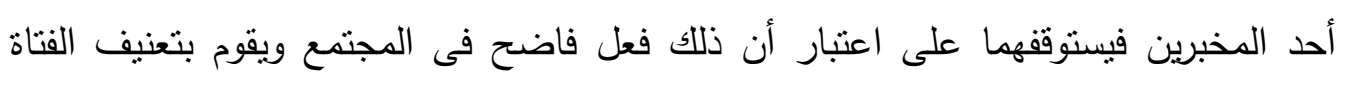

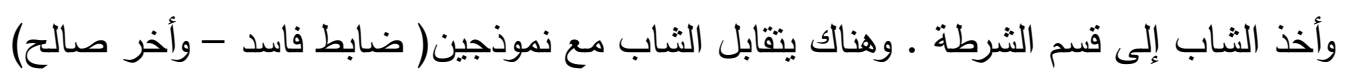
فيآمر الأول بحبسه داخل الزنزانة وذلك بعد أن بنهال عليه سباً وقذفاً.

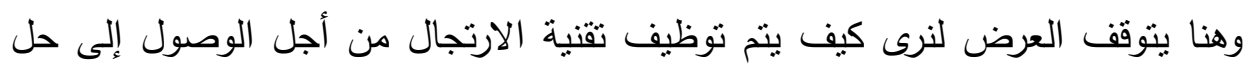

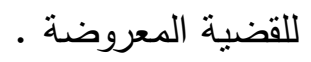
فنجد أن مسرح المقهورين قائم فى الأساس على فكرة يتم الاتفاق عليها تعالج مشكلة

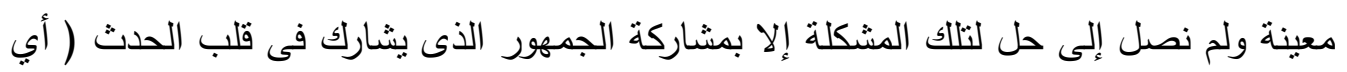
يصعد إلى منصة التمثيل أى كان نوعها ويتقص شخص إلىصية المقهور لنرى ردود أفعاله لما يقوم

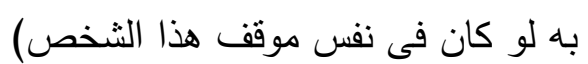
وبالتالى نجد الآتى: بانى

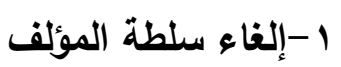

فالعرض هنا غير مرتبط بنص معين أى غير موجود له script ولكن هى فكرة نم الاتفاق عليها مسبقاً ويتم معالجتها وفقاً لإستجابات الجمهور من أجل الوصول إلى حلى فئ النهائة

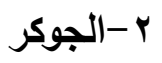
ونجد أن " شخصية الجوكر ذات وظائف متعددة فى تلك العروض ، ويقوم بدور المدرب

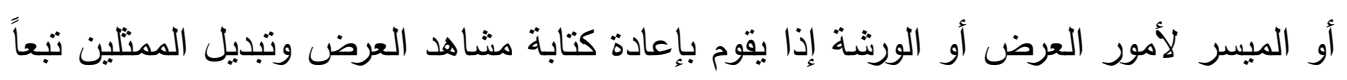

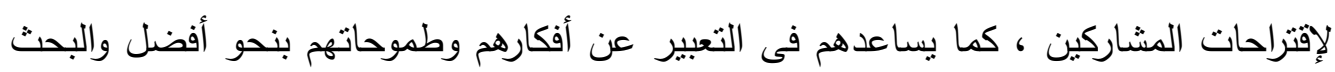

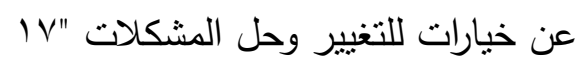
وقام أحمد سالم بدور الجوكر فى هذا العرض فنجده بعد يتوقف العرض يحث الجمهور

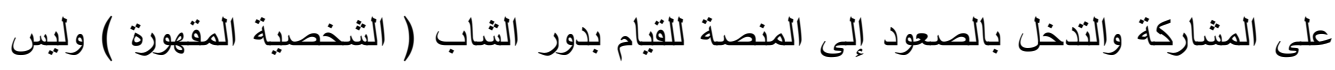
دور القاهر الذى هو من مصلحته فكرة القهر .وكانت استجابات المشاركين كالتالى : 
- مشارك ( ) لايصح أن يضع خطيب يده على خطيبته لأن العلاقة بينهما ما زالت غير شرعية - مشارك (r) اعترض على الاخول إلى الزنزانة لأننى غير مرتكب جريمة بصفة رسمية - مشارك (r) اعترض على الذهاب مع المخبر لأن ذلك حرية شخصية ولاداعى لأحد للتنذخل فيها.

وبيدأ الجوكر بالتقريب بين وجهات النظر من أجل الوصول إلى الحلول المقنعة التى تساهم فى الخروج من حالة القهر.

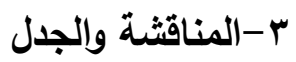

طالما حدث تقريب بين وجهات النظر إذن لابد أن يتذخل النقاش مع الجمهور المشارك ،

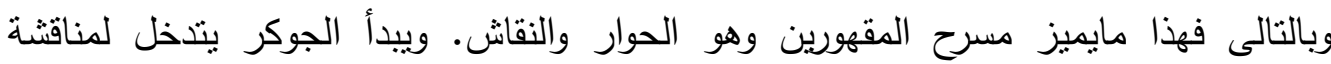
الأفكار المطروحة وكان تركيزه حول أن لكل فعل خطأ سند قانونى لابد من اللجوء إليه لكى يتم توقيع العقوبة. فالثاب دخل الزنزانة بدون إثبات على فعل غير شهادة المخبر التى ربما بطعن بها الثاب ويتهمه أنه كان يتعدى على خطييته بالتحرش الجنسى مثناً.

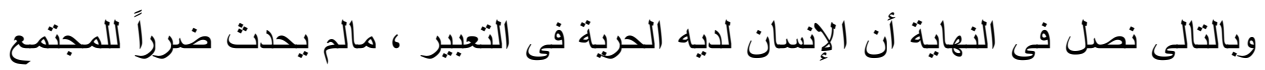
الذى يعيش فيه وإذا حدث ضرر لابد من سند قانونى لأى فعل خاطيء لكى يتم العقاب. من مجمل العرض السابق يمكن أن نستتنج الآتى: لإنى العرض كله قائم على الإرتجال

1-الفكرة : تم الاتفاق عليها ولكن مع عدم وجود نص مكتوب يلتزم به ممنلوا العرض ، وإنما

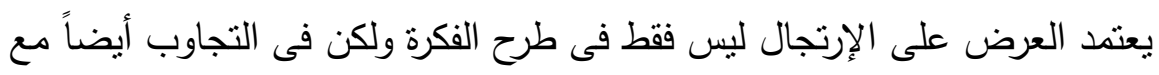
المشاركين عندما يوجه لهم أى ردود أفعال.

ץ-المشاركين : يقوموا بالارتجال من أجل إيجاد حلول للمشكلة المعروضة ودهم لئهم ليس لديهم خلفية مسبقة بها ولكن هو مجرد موقف معروض أمامهم ويتطلب الحل.

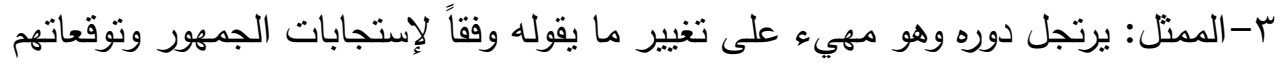

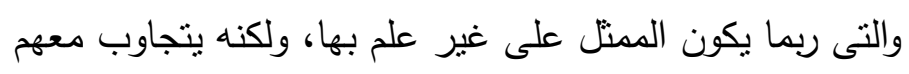

\section{العرض الثانى " حكاية سماح"}

يتتاول العرض قضية العنف والقسوة فى تربية الأبناء أو الحماية الزائدة ( الخوف من أى شيء) فسماح فتاة فى السادسة عشلر من عمرها يجبرها والدها على عدم الخروج من المنزل

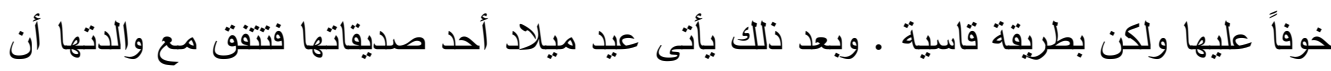


تذهب إليه مع عدم علم والدها ، وتتقابل سماح مع أخاها وهى خارجة من المنزل إلى بيت

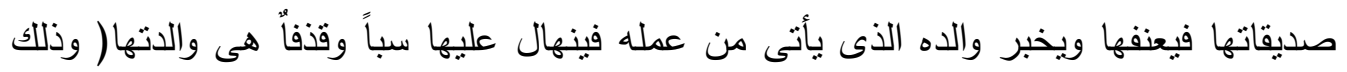

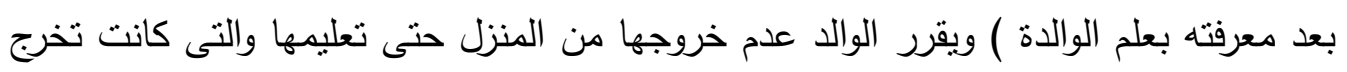

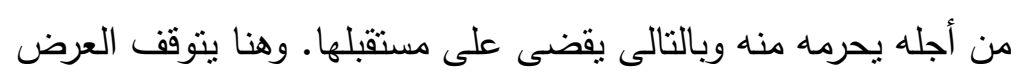

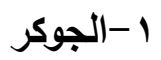

يتدخل الجوكر ( أحمد سالم) ويعمل على تحفيز الجمهور على الإنخراط فى العرض والمشاركة بشكل فعلى عن طريق الصعود إلى المنصة وتقص دور المقهور ( شخصية سماح)

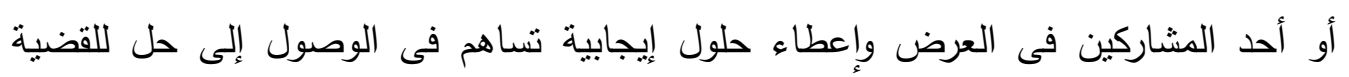
المعروضة.

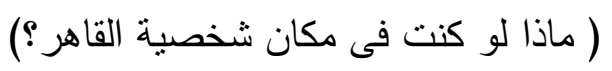

وكانت استجابات المشاركين كالتالى:-

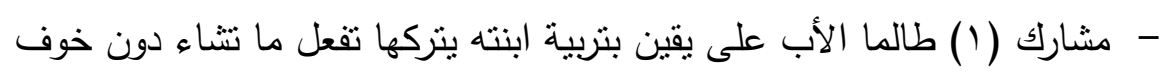

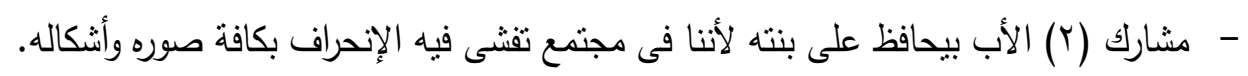

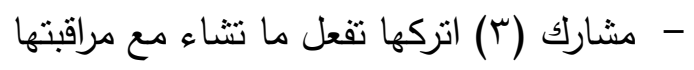
ويحاول الجوكر ألا يفرض رأياً على الجمهور المشارك ولكنه يعطيه الحرية مع توجيهه

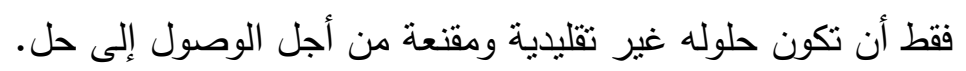

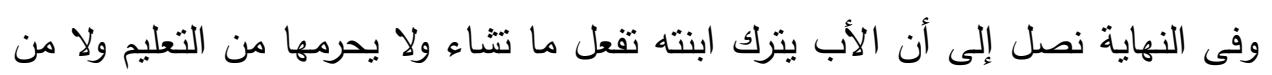

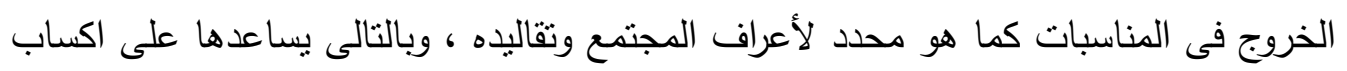

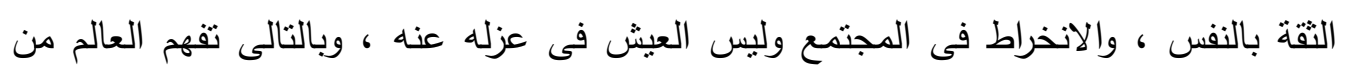
حولها.

\section{r-المناقثة}

اعتمد عرض " حكاية سماح" على مشهد قصير تم طرح المشكلة من خلاله. وبعد ذلك الكة

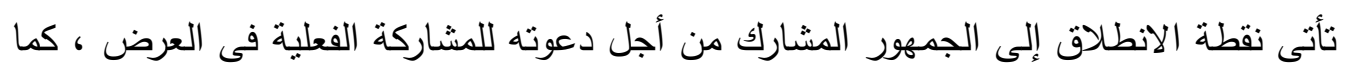

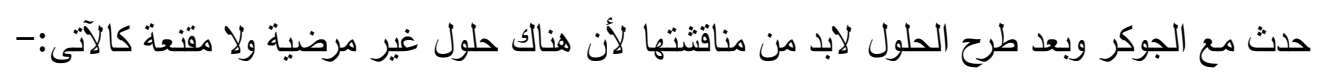

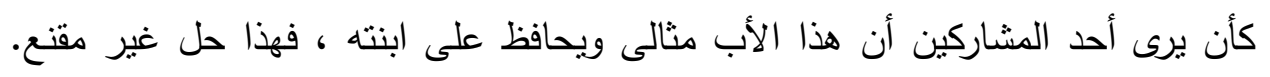
لأنه يحرمها من الحقوق التى كفلها لها المجتمع. 
أن العرض قائم على الارتجال ولكن كانت هناك نواحى قصور من قبل المشاركين

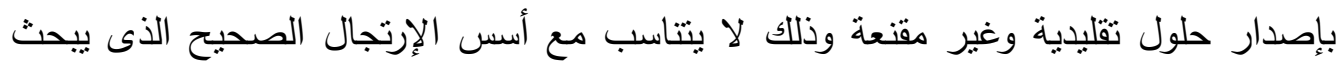

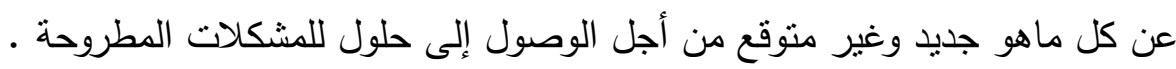
حكاية " سكر " مل حل

يقدم العرض قضية أطفال الثوارع وما يتعرضون له ـ ـ فهاهو سكر طفل من أطفال

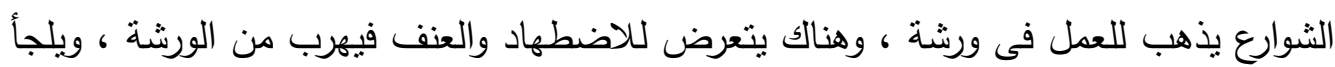

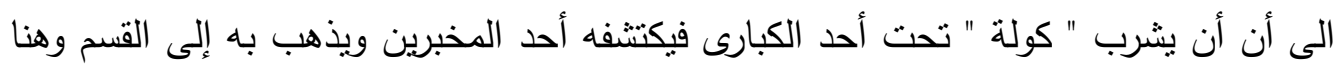
يتوقف العرض ان لينرب

الجوكر

تدخل الجوكر الذى يقود حوارا و نقانثا مع الجمهور حتى يظهر متفرج منظوع بفكرة. للقيام بالمشاركة الفعلية فى العرض ، كما يتعين على جميع المشاركين عدم اقتراح حلول خيالية

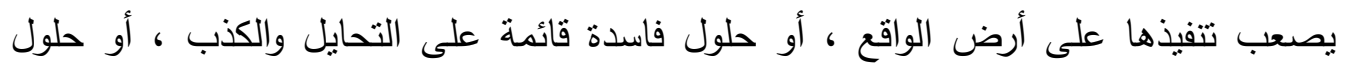

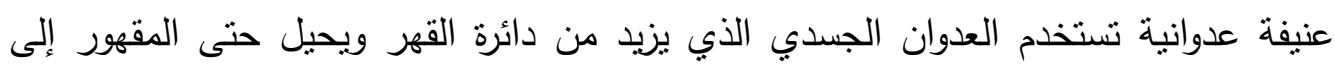
قاهر

\section{المناقثة والجدل}

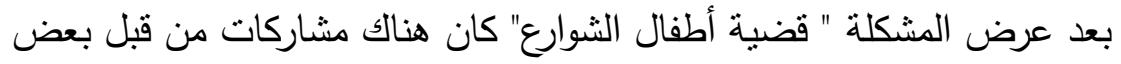
المشاركين للمشاركة الفعلية في معالجة القضية.

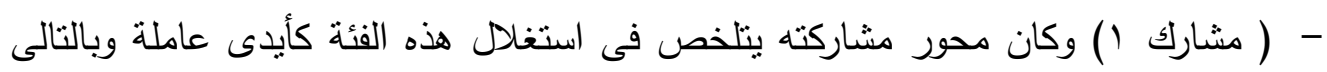

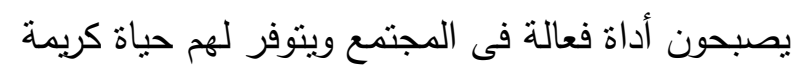

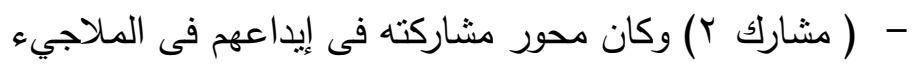

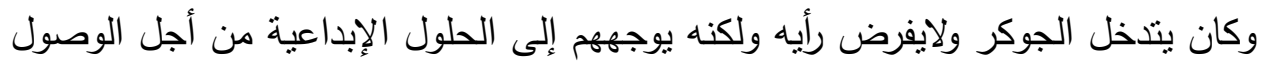
إلى حل.

\section{نتائج الاراسة}

- اسفرت النتائج على أن أهم أسس الارتجال سواء فى عروض مسرح الراقص أو مسرح

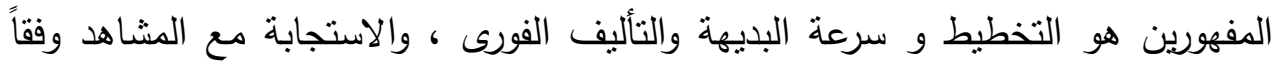

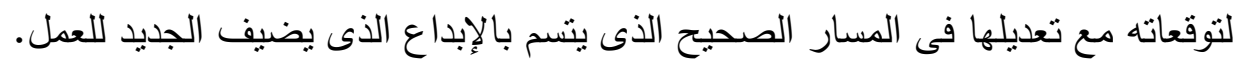
- أوضحت النتائج أن الراقص فى العروض فئه عينة الدراسة على دراية بمعرفة أماكن الارتجال الصحيحة التى يمكن أن تضيف الجديد للعمل 
- ان العروض المقدمة لمسرح المقهورين ( عينة الدراسة ) تتصب على التركيز على المتفرج

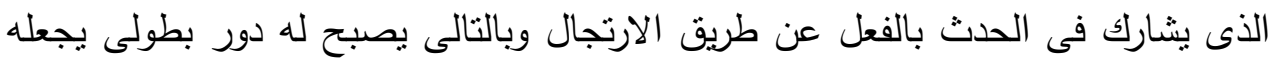
قادرا على القيام بالفعل الحقيقى فى الحياة. - المتفرج فى عروض مسرح المقهورين ( عينة الدراسة ) نجده حاول ألا يقف موقف المتفرج وإنما شارك بالفعل فى العرض وقدم مداخلات مرتجلة مع الممثلين أفسحت المجال

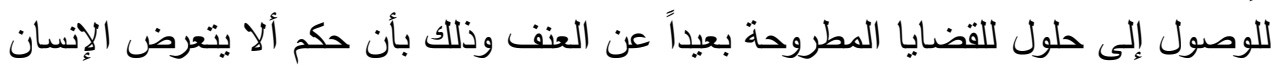

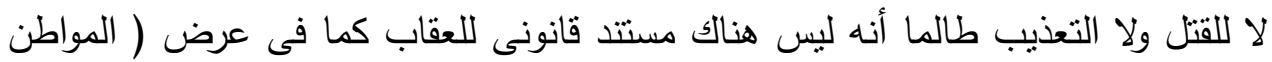

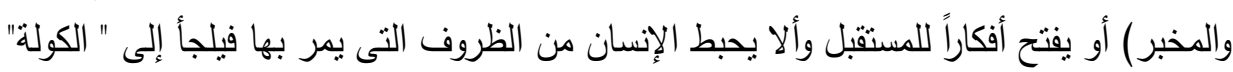
- تتوعت الأهداف التى كانت وراء توظيف تقنية الارتجال فى العروض عينة الدراسة وكان فى مقدمتها:تحقيق القدرة على التخيل وترك الحربة للراقص لإبداع حركات جديدة تساهم فى إضافة

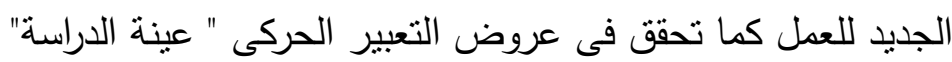

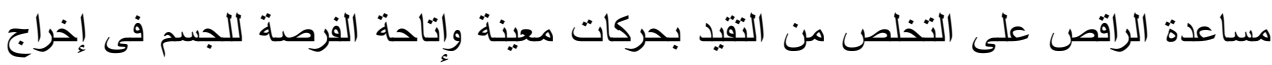
كل ما يمتلكه من قدرات. إتاحة الفرصة للمشارك فى عروض مساك مسرح المقهورين بالتعرف على أسس الإرتجال الصحيحة التى تضيف الجديد للعمل.

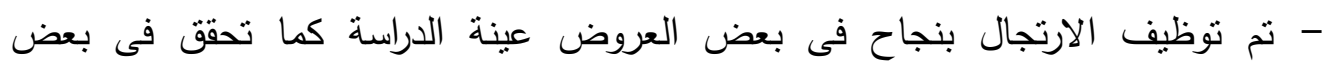
العروض عينة الدراسة وإن حدث إخفاقاً فى الحركات العشوائية التى كان يقوم بها أحد أحدان راقصى العرض والتى كانت ترجمة للحوار الذى نم سرده حول قصة دكتور يحيى وغيابه

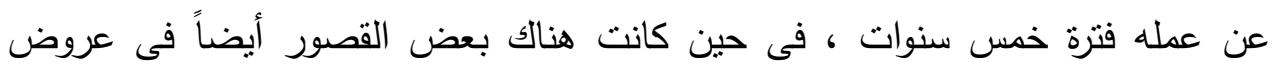

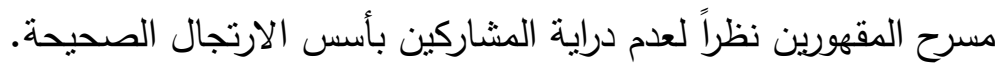

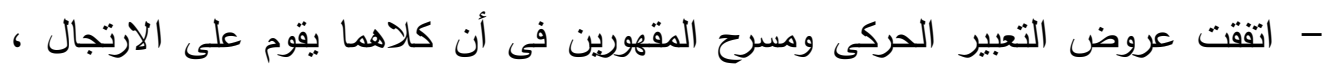

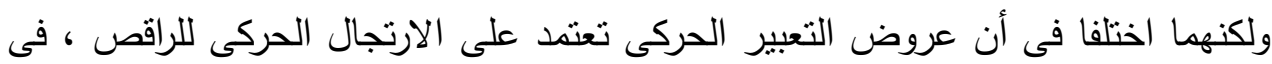

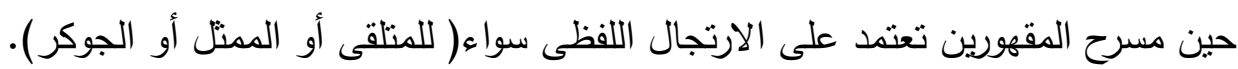

توصيات البحث

- الارتجال ليس عملية سهلة بل يحتاج مزيداً من التدريب وأن من يقوم به لابد أن يكون على الئ دراية بأسس الارتجال الجيد حتى ينجح فى أداء دوره.

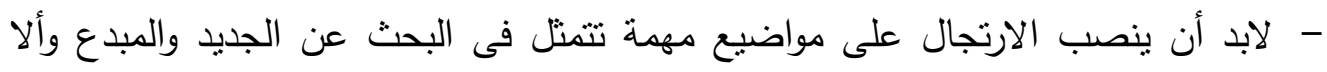

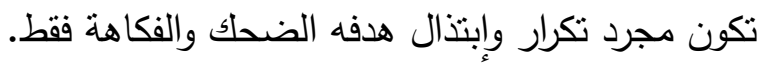


- الارتجال لابد أن يضيف فى إكمال بناء المشهد فنرى له حبكة أو تيمة معينة وليس مجرد عرض فكرة فقط. - الإكثار من تدريبات الارتجال ولا تكون قاصرة على الممنل فقط ولكن تتضمن المشاركين

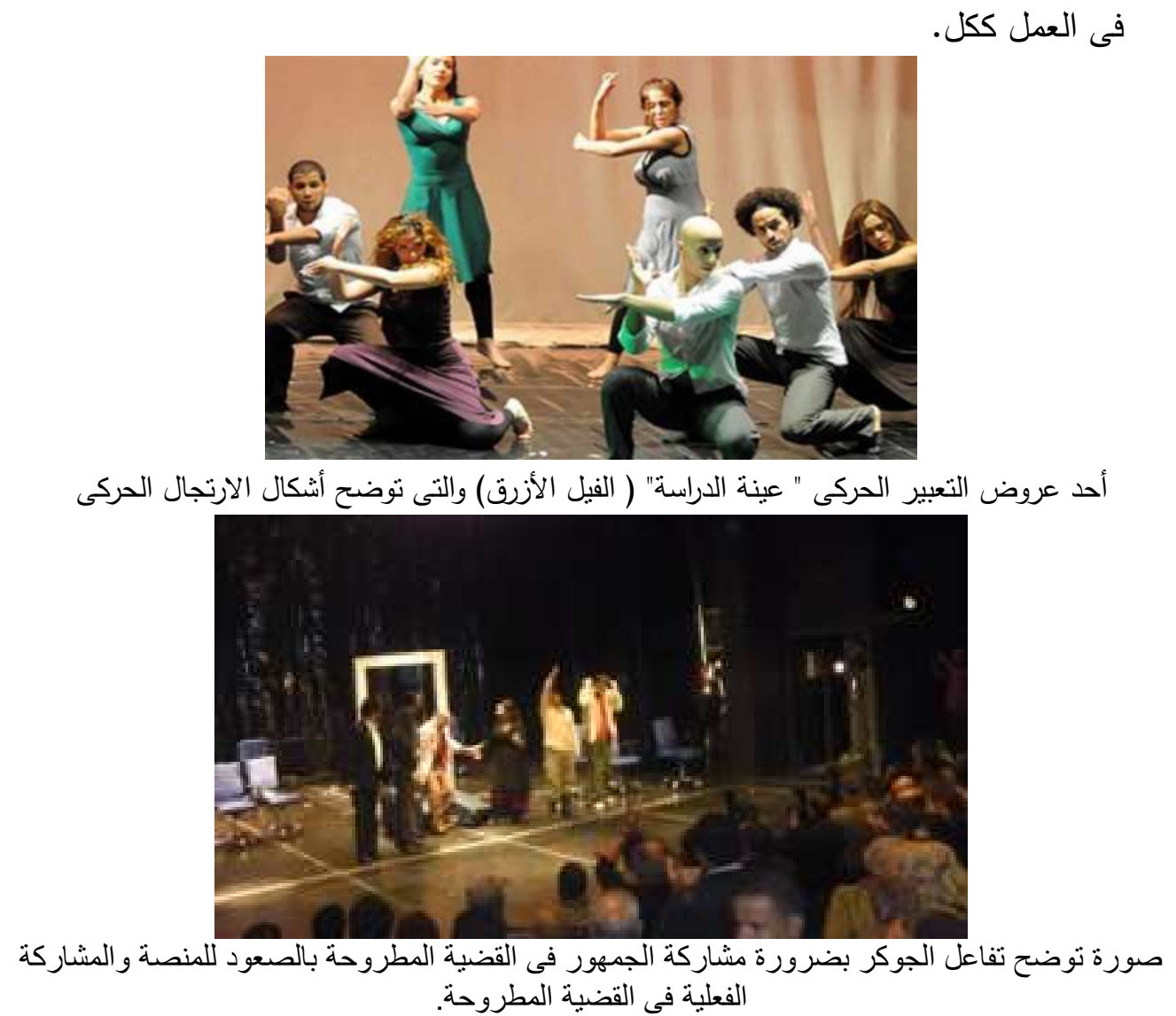
الفعلية فى القضية المطروحة فئة الفية 
1- أحمد زكى : الإخراج المسرحى ( القاهرة ، الهيئة المصرية العامة للكتاب ، 919 (1) ) ץ- أثثر السادة : أوجستوبوال - مسرح المقهورين ( القاهرة ، سلسلة المسرح العالمى ، 9 ، . † ) r- انثونى فروست ورالف يارو : الارتجال فى الدراما ، نرجمة : مركز اللغات والترجمة بأكاديمية

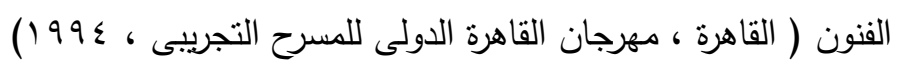
ع - أوجستوبوال : مسرح المقهورين - تدريبات عملية ، ترجمة / أسامة أبو طالب ( القاهرة ، مهرجان

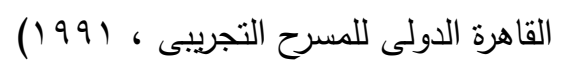
ه- جيرهارد إييرت : الارتجال وفن التمثيل المسرحى - دراسة فى إبداعية الممنل ، ترجمة / حامد

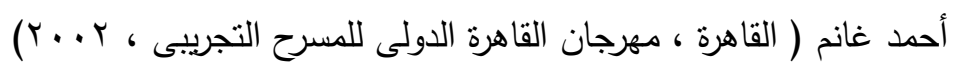

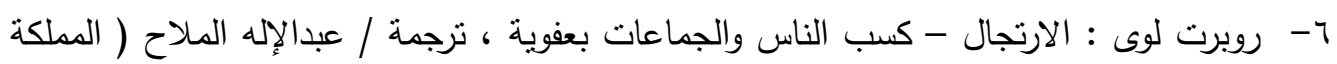

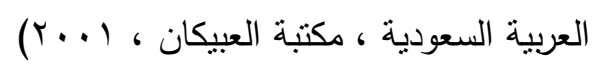
V- حسن المنيعى : المسرح والارتجال ( الدار البيضاء ، بو 199) 1- سعيد كريمى : محمد الكغاط بين هاجس التجريب والإرتجال المسرحى ( المغرب ، مجلة كلية

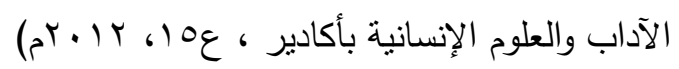
9- فايز زبد السهيل : توظيف عنصرى الإلقاء والارتجال بين إخراج العروض المسرحية والتليفزيونية

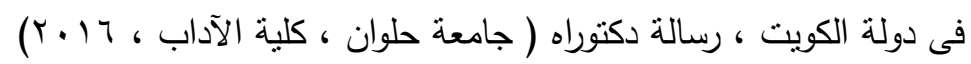
• ا- فيولا سبولين : الارتجال المسرحى ، ترجمة / سامى صلاح ( وزارة الثقافة ، مهرجان القاهرة

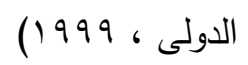
1ا- كيث جونستون : الارتجال والمسرح ، ترجمة : عبد الوهاب محمود خضر ( مهرجان القاهرة

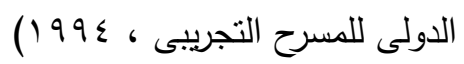

ب ا-مروة الحسينى محمد توفيق : فاعلية برنامج مقترح للارتجال فى تتمية التعبير اللفظى لاى الروضة

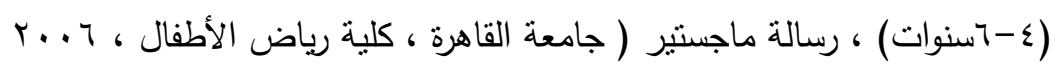

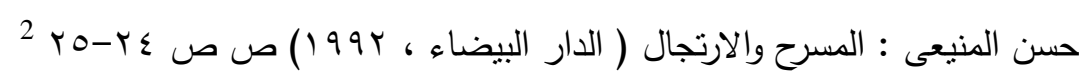
3ربرت لوى : الارتجال - كسب الناس والجماعات بعفوية ، ترجمة / عبدالإله الملاح ( المملكة

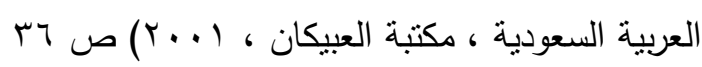
مروة الحسينى محمد توفيق : فاعلية برنامج مقترح للارتجال فى تتمية التعبير اللفظى لدى الروضة

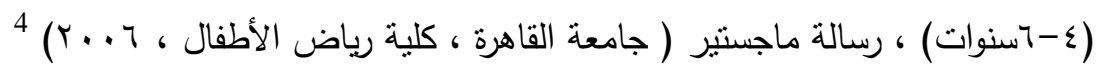


سعيد كريمى : محمد الكغاط بين هاجس التجريب والإرتجال المسرحى ( المغرب ، مجلة كلية الآداب

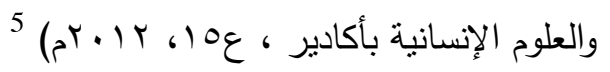

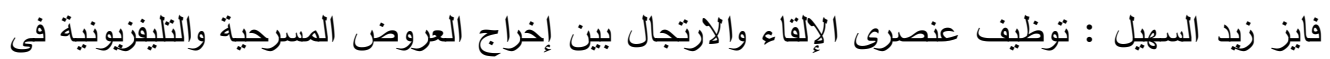

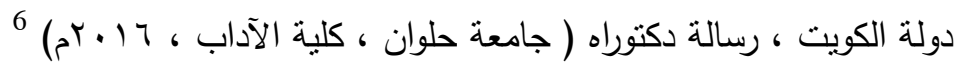

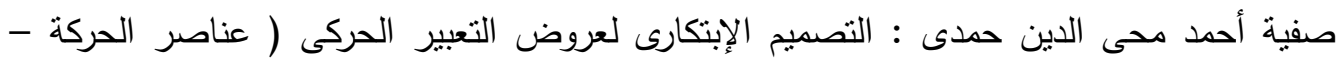

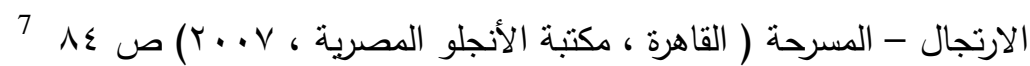

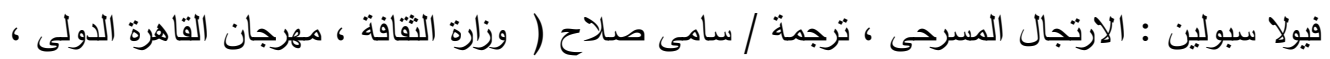

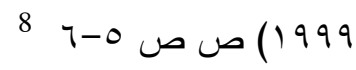

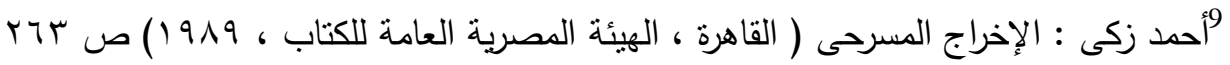

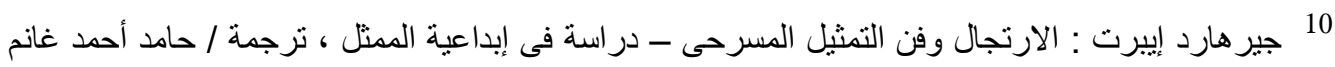

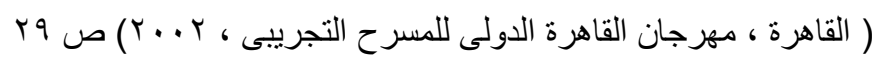

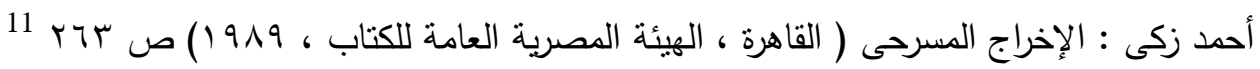

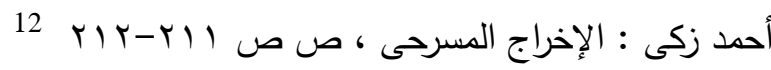
13 انشونى فروست ورالف يارو : الارتجال فى الدراما ، ترجمة : مركز اللغات والترجمة بأكاديمية

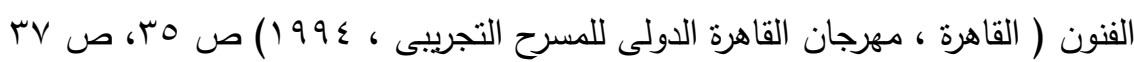

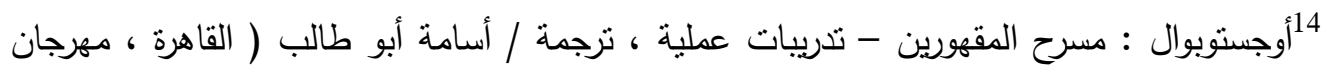

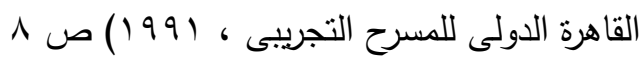
كيث جونستون : الارتجال والمسرح ، ترجمة : عبد الوهاب محمود خضر الورل ( مهرجان القاهرة الدولى

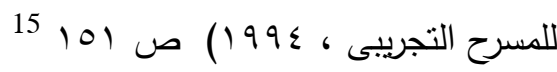

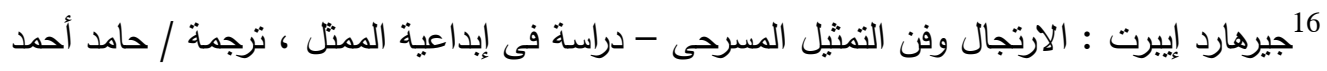

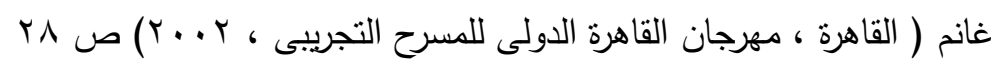

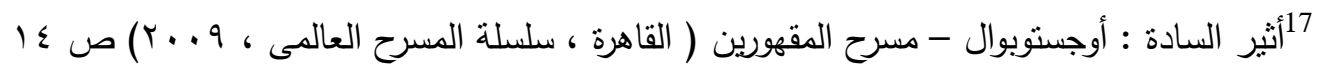

